\title{
Editorial \\ Plant-Based Bioactive Natural Products: Insights into Molecular Mechanisms of Action
}

\author{
Hari Prasad Devkota $\mathbb{D}$
}

Citation: Devkota, H.P. Plant-Based Bioactive Natural Products: Insights into Molecular Mechanisms of Action. Appl. Sci. 2021, 11, 10220. https:// doi.org/10.3390/app112110220

Received: 21 October 2021

Accepted: 26 October 2021

Published: 1 November 2021

Publisher's Note: MDPI stays neutral with regard to jurisdictional claims in published maps and institutional affiliations.

Copyright: (C) 2021 by the author. Licensee MDPI, Basel, Switzerland. This article is an open access article distributed under the terms and conditions of the Creative Commons Attribution (CC BY) license (https:/ / creativecommons.org/licenses/by/ $4.0 /)$.
Graduate School of Pharmaceutical Sciences, Kumamoto University, 5-1 Oe-honmachi, Chuo-ku, Kumamoto 862-0973, Japan; devkotah@kumamoto-u.ac.jp

Keywords: natural products; bioactive compounds; medicinal plants; bioactivity; mechanism of action; traditional medicines

Medicinal plants have been used for the maintenance of human health since ancient times in the form of food, spices, and traditional medicines [1-3]. Traditional plant-based medicines serve as the primary healthcare systems in various countries even in recent times [4,5]. Additionally, medicinal plants have also served as the one of the main sources for the discovery of new therapeutic agents $[3,6]$.

At present, various plant extracts and their isolated phytochemicals are screened and evaluated for their diverse pharmacological activities related to both communicable and non-communicable diseases. However, comparatively little focus is given to the detailed mechanism of action of these agents on the molecular level. Molecular mechanismbased studies are essential for the development of evidence-based traditional medicines as well as for the development of isolated natural products as the lead candidates for novel drug discovery.

This main focus of this Special Issue "Plant-based Bioactive Natural Products: Insights into Molecular Mechanisms of Action" is to cover the recent advances in science related to the molecular mechanisms of action of natural products. A total of nine articles were published under this Special Issue including seven original research articles and two review articles.

Food by-products have been receiving great attention in recent years for their valorization to obtain bioactive natural products that can contribute to sustainable development and circular economy [7-9]. In this issue, López-Salas et al. [10] reported the potential of artichoke by-products as a rich source of phenolic compounds. The authors optimized the extraction condition for polyphenols using an advanced extraction technique, pressurized liquid extraction (PLE), with ethanol-water mixture as solvent. Compounds were identified by using high-performance liquid chromatography (HPLC) coupled to electrospray time-of-flight mass spectrometry (HPLC-ESI-TOF/MS) analysis.

Colone et al. [11] reported the potent antiproliferative activity of essential oil (EO) obtained from the leaves of Vepris macrophylla against human breast adenocarcinoma cell line SKBR3.

Lee et al. [12] reported the memory improving activity of $70 \%$ ethanol extract of roots of Scrophularia buergeriana in model mice with beta-amyloid-induced memory loss. The extract improved the memory impairment by reducing neurotoxicity and regulating oxidative stress and inhibiting the apoptosis pathway. The authors further analyzed the memory improving activity of the extract in scopolamine-induced neuronal impairment in mice [13]. The extract was reported to inhibit the acetylcholinesterase activity and to exert memory-improving effects through the phosphorylated cAMP response element-binding (CREB) and brain-derived neurotrophic factor (BDNF) pathway.

Fruits of Terminalia chebula are used as crude drugs in many traditional medicine systems around the world due to potent antioxidant, hepatoprotective and anti-diabetic 
activities [14]. Kim et al. [15] reported the anti-osteoarthritic activity of aqueous extracts of Terminalia chebula fruit in interleukin- $1 \beta$-induced human chondrocytes and monosodium iodoacetate-induced osteoarthritis in model rats.

Jun et al. [16] reported the vascular inflammation preventive activity of liensinine, a bisbenzylisoquinoline alkaloid found in Nelumbo nucifera. Liensinine showed potent in vitro antioxidative and anti-inflammatory activity by attenuating inflammatory mediators in human vascular smooth muscle cells (VSMC).

Badger-Emeka et al. [17] reported the synergistic activity of cold pressed oil of Nigella sativa with various $\beta$-lactam antibiotics against clinical isolates of methicillin-resistant Staphylococcus aureus (MRSA).

Ullah et al. [18] reported a comprehensive review on the role of plant extracts and their isolated phytochemicals against food-borne pathogens, one of the major causative agents of food-borne illness worldwide.

Tundis et al. [19] reported an extensive review on the traditional uses, bioactive chemical constituents and biological properties of various species of Vaccinium genus. The authors also highlighted their potential uses in functional food and cosmetic markets.

This Special Issue has provided some new experimental data on bioactive natural products and their detailed mechanisms of action for biological activities. Similarly, review articles have provided state-of-the-art information on the related topics. I would like to thank all the authors for submitting their manuscripts and the reviewers and editors for their contribution to this Special Issue. Furthermore, I am also grateful to the handling editors and staff of Applied Sciences for their support during the preparation and finalization of this Special Issue.

Funding: This research received no external funding.

Conflicts of Interest: The author declares no conflict of interest.

\section{References}

1. Kunwar, R.M.; Bussmann, R.W. Ethnobotany in the Nepal Himalaya. J. Ethnobiol. Ethnomed. 2008, 4, 24. [CrossRef] [PubMed]

2. Khanal, A.; Devkota, H.P.; Kaundinnyayana, S.; Gyawali, P.; Ananda, R.; Adhikari, R. Culinary herbs and spices in Nepal: A review of their traditional uses, chemical constituents, and pharmacological activities. Ethnobot. Res. Appl. 2021, $21,40$.

3. Atanasov, A.G.; Waltenberger, B.; Pferschy-Wenzig, E.M.; Linder, T.; Wawrosch, C.; Uhrin, P.; Temml, V.; Wang, L.; Schwaiger, S.; Heiss, E.H.; et al. Discovery and resupply of pharmacologically active plant-derived natural products: A review. Biotechnol. Adv. 2015, 33, 1582-1614. [CrossRef] [PubMed]

4. Cordell, G.A.; Colvard, M.D. Some thoughts on the future of ethnopharmacology. J. Ethnopharmacol. 2005, 100, 5-14. [CrossRef]

5. Yuan, H.; Ma, Q.; Ye, L.; Piao, G. The traditional medicine and modern medicine from natural products. Molecules 2016, $21,559$. [CrossRef]

6. David, B.; Wolfender, J.L.; Dias, D.A. The pharmaceutical industry and natural products: Historical status and new trends. Phytochem. Rev. 2015, 14, 299-315. [CrossRef]

7. Durazzo, A.; Lucarini, M.; Santini, A. Plants and Diabetes: Description, Role, Comprehension and Exploitation. Int. J. Mol. Sci. 2021, 22, 3938. [CrossRef]

8. Vermeir, I.; Weijters, B.; De Houwer, J.; Geuens, M.; Slabbinck, H.; Spruyt, A.; Van Kerckhove, A.; Van Lippevelde, W.; De Steur, H.; Verbeke, W. Environmentally Sustainable Food Consumption: A Review and Research Agenda From a Goal-Directed Perspective. Front. Psychol. 2020, 11, 1603. [CrossRef] [PubMed]

9. Torres-León, C.; Ramírez-Guzman, N.; Londoño-Hernandez, L.; Martinez-Medina, G.A.; Díaz-Herrera, R.; Navarro-Macias, V.; Alvarez-Pérez, O.B.; Picazo, B.; Villarreal-Vázquez, M.; Ascacio-Valdes, J.; et al. Food Waste and Byproducts: An Opportunity to Minimize Malnutrition and Hunger in Developing Countries. Front. Sustain. Food Syst. 2018, 2, 52. [CrossRef]

10. López-Salas, L.; Borrás-Linares, I.; Quintin, D.; García-Gomez, P.; Giménez-Martínez, R.; Segura-Carretero, A.; Lozano-Sánchez, J. Artichoke By-Products as Natural Source of Phenolic Food Ingredient. Appl. Sci. 2021, 11, 3788. [CrossRef]

11. Colone, M.; Maggi, F.; Rakotosaona, R.; Stringaro, A. Vepris macrophylla Essential Oil Produces Notable Antiproliferative Activity and Morphological Alterations in Human Breast Adenocarcinoma Cells. Appl. Sci. 2021, 11, 4369. [CrossRef]

12. Lee, H.J.; Lee, D.Y.; Kim, H.L.; Yang, S.H. Scrophularia buergeriana Extract Improves Memory Impairment via Inhibition of the Apoptosis Pathway in the Mouse Hippocampus. Appl. Sci. 2020, 10, 7987. [CrossRef]

13. Lee, H.-J.; Kim, H.-L.; Lee, D.-Y.; Lee, D.-R.; Choi, B.-K.; Yang, S.-H. Scrophularia buergeriana Extract (Brainon) Improves Scopolamine-Induced Neuronal Impairment and Cholinergic Dysfunction in Mice through CREB-BDNF Signaling Pathway. Appl. Sci. 2021, 11, 4286. [CrossRef] 
14. Nigam, M.; Mishra, A.P.; Adhikari-Devkota, A.; Dirar, A.I.; Hassan, M.M.; Adhikari, A.; Belwal, T.; Devkota, H.P. Fruits of Terminalia chebula Retz:: A review on traditional uses, bioactive chemical constituents and pharmacological activities. Phyther. Res. 2020, 34, 2518-2533. [CrossRef] [PubMed]

15. Kim, H.L.; Lee, H.J.; Lee, D.-R.; Choi, B.-K.; Yang, S.H. Anti-Osteoarthritic Effects of Terminalia Chebula Fruit Extract (AyuFlex $\left.{ }^{\circledR}\right)$ in Interleukin-1 $\beta$-Induced Human Chondrocytes and in Rat Models of Monosodium Iodoacetate (MIA)-Induced Osteoarthritis. Appl. Sci. 2020, 10, 8698. [CrossRef]

16. Jun, M.Y.; Karki, R.; Paudel, K.R.; Panth, N.; Devkota, H.P.; Kim, D.-W. Liensinine Prevents Vascular Inflammation by Attenuating Inflammatory Mediators and Modulating VSMC Function. Appl. Sci. 2021, 11, 386. [CrossRef]

17. Badger-Emeka, L.I.; Emeka, P.M.; Ibrahim, H.I.M. A Molecular Insight into the Synergistic Mechanism of Nigella sativa (Black Cumin) with $\beta$-Lactam Antibiotics against Clinical Isolates of Methicillin-Resistant Staphylococcus aureus. Appl. Sci. 2021, 11, 3206. [CrossRef]

18. Ullah, F.; Ayaz, M.; Sadiq, A.; Ullah, F.; Hussain, I.; Shahid, M.; Yessimbekov, Z.; Adhikari-Devkota, A.; Devkota, H.P. Potential Role of Plant Extracts and Phytochemicals Against Foodborne Pathogens. Appl. Sci. 2020, 10, 4597. [CrossRef]

19. Tundis, R.; Tenuta, M.C.; Loizzo, M.R.; Bonesi, M.; Finetti, F.; Trabalzini, L.; Deguin, B. Vaccinium Species (Ericaceae): From Chemical Composition to Bio-Functional Activities. Appl. Sci. 2021, 11, 5655. [CrossRef] 